\title{
Pengembangan multimedia powerpoint berbasis problem solving untuk siswa kelas X MIA SMA
}

\author{
Agustin Fatmawati, Sentot Kusairi*, Sutopo \\ Universitas Negeri Malang, Jl. Semarang No. 5 Malang, Jawa Timur, Indonesia \\ *Penulis korespondensi, Surel: sentot.kusairi.fmipa@um.ac.id
}

Paper received: 01-07-2021; revised: 15-07-2021; accepted: 31-07-2021

\begin{abstract}
Abstrak
Tujuan dari penelitian dan pengembangan ini adalah mengembangkan multimedia powerpoint berbasis problem solving pada materi suhu dan kalor untuk siswa kelas X MIA SMA dan mengetahui kelayakan produk yang dibuat. Langkah-langkah pada penelitian ini yaitu: (1) potensi dan masalah, (2) pengumpulan data, (3) desain produk, (4) validasi desain, (5) revisi desain, (6) uji coba produk, dan (7) revisi produk. Berdasarkan hasil analisis, diketahui bahwa nilai rata-rata validasi produk oleh ahli adalah 3,33 , nilai rata-rata validasi soal dan pembahasan dari ranah materi secara keseluruhan 3,77 dan dari ranah konstruksi secara keseluruhan sebesar 3,50. Sedangkan berdasarkan hasil uji coba pemakaian ke siswa didapatkan hasil multimedia powerpoint berbasis problem solving dapat membuat siswa membuat lebih bersemangat dan lebih mudah memahami materi suhu dan kalor. Siswa tidak menemukan kendala yang berarti dalam menggunakan media pembelajaran. Hal ini menunjukkan bahwa produk yang dikembangkan dalam penelitian ini layak. Produk selanjutnya siap untuk diujikan skala luas.
\end{abstract}

Kata kunci: Multimedia Powerpoint; Problem Solving; Suhu dan Kalor

\section{Pendahuluan}

Fisika sebagai ilmu pengetahuan telah berkembang sejak abad ke-14 . Fisika bersamasama dengan biologi, kimia, serta astronomi tercakup dalam kelompok-kelompok ilmu-ilmu alam (natural science). Fisika merupakan ilmu yang mempelajari fenomena alam dalam berbagai bentuk gejala untuk dapat memahami apa yang mengendalikan atau menentukan fenomena tersebut. Belajar fisika tidak lepas dari penguasaan konsep-konsep dasar fisika melalui pemahaman sehingga dengan menggunakan pemahaman tersebut siswa mampu menjelaskan berbagai permasalahan yang ada. Dalam belajar fisika, yang pertama dituntut adalah kemampuan untuk memahami konsep, prinsip maupun hukum-hukum, kemudian diharapkan siswa mampu menyusun kembali dalam bahasanya sendiri sesuai dengan perkembangan intelektualnya

Pembelajaran fisika dipandang sebagai suatu proses untuk mengembangkan kemampuan memahami konsep, prinsip maupun hukum-hukum fisika sehingga dalam proses pembelajarannya harus mempertimbangkan strategi atau metode pembelajaran yang efektif dan efiesien. Menurut Domi (2013) dalam penelitiannya, pembelajaran fisika merupakan proses menciptakan kondisi dan peluang agar siswa dapat mengkonstruksi pengetahuan, ketrampilan proses dan sikap ilmiahnya. Berdasarkan hal tersebut, dalam pembelajaran fisika siswa diharapkan dapat memahami serta menerapkan konsep dan prinsip-prinsip fisika untuk menyelesaikan masalah baik bersifat kualitatif maupun kuantitatif.

Kebutuhan mengenai kemampuan siswa dalam menyelesaikan masalah tercantum dalam Permendikbud Nomor 69 tahun 2013 tentang Kerangka Dasar dan Struktur Kurikulum SMA/MA. Kurikulum 2013 dikembangkan menggunakan filosofi pendidikan untuk membangun kehidupan masa kini dan masa depan yang 
lebih baik dari masa lalu dengan berbagai kemampuan intelektual, kemampuan berkomunikasi, sikap sosial, kepedulian, dan berpartisipasi untuk membangun kehidupan masyarakat dan bangsa yang lebih baik (experimentalism and social reconstructivism). Dengan filosofi ini, Kurikulum 2013 bermaksud untuk mengembangkan potensi peserta didik menjadi kemampuan dalam berpikir reflektif bagi penyelesaian masalah sosial di masyarakat, dan untuk membangun kehidupan masyarakat demokratis yang lebih baik. Kemampuan menyelesaikan masalah menuntut siswa untuk mengidentifikasi, mendefinisikan dan memecahkan masalah menggunakan logika serta pemikiran kreatif. Dalam proses ini, siswa memiliki pemahamahan yang mendalam tentang topik, membangun pengetahuan baru dan mampu membuat keputusan (Crebet, 2011).

Meskipun keterampilan pemecahan masalah itu penting, kemampuan siswa dalam hal ini adalah rendah. Penelitian yang dilakukan oleh Bayon (2013) menunjukkan bahwa sebanyak $83,3 \%$ siswa masih memiliki kemampuan pemecahan masalah yang rendah. Sebanyak 70\% siswa kesulitan dalam menggunakan persamaan atau rumus dalam soal. Selain itu, siswa merasa mengalami kesulitan dalam menghubungkan soal dengan rumus pada bab sebelumnya. Kesulitan yang dialami siswa diakibatkan oleh kurangnya pemahaman konsep, kecenderungan untuk menghafal rumus, serta kebisaan menyelesaikan soal hitungan pada bahan ajar yang digunakan. Hal tersebut didukung dengan kenyataan pembelajaran di dalam kelas

Kenyataannya masih terdapat siswa yang belum tuntas dalam memahami materi yang dijelaskan di dalam kelas. Fakta tersebut dapat menjadi salah satu penyebab kurangnya kemampuan siswa dalam menyelesaikan masalah. Namun pada dasarnya, setiap siswa dapat dibantu secara individul maupun kelompok untuk meningkatkan pemahaman siswa agar tuntas dalam belajar fisika. Oleh sebab itu diperlukan solusi agar siswa memiliki ketuntasan dalam belajar fisika. Alternatif pertama yaitu dengan memberikan kegiatan pembelajaran tambahan diluar jam pelajaran agar siswa memiliki tambahan waktu untuk memahami materi. Akan tetapi hal ini akan menemukan kendala ketika guru tidak memiliki waktu yang lebih diluar jam pelajaran. Alternatif kedua yaitu dengan tutor sebaya. Siswa yang telah mampu memahami dengan baik materi pembelajaran dapat mengajarkan ke teman lainnya yang belum mampu memahaminya. Alternatif ketiga untuk meningkatakan pemahaman siswa juga dapat melalui pemberian tugas. Akan tetapi tugas yang diberikan ke siswa akan menjadi kurang efektif ketika yang mengerjakan tugas itu nanti bukan siswa itu sendiri.

Berdasarkan penjelasan di atas maka perlu dilaksanakan pembelajaran remidial. Pembelajaran remidial adalah suatu bentuk pembelajaran yang bersifat menyembuhkan atau membetulkan atau pembelajaran yang membuat menjadi baik (Depdikbud, 1984:5). Sedangkan menurut Murwatiningsih (2007) pembelajaran remidial merupakan bentuk pembelajaran khusus yang ditujukan untuk perbaikan sebagian atau seluruh kesulitan belajar yang dihadapi oleh siswa yang diarahkan pada pencapaian hasil belajar yang optimal sesuai kemampuan siswa melalui proses pembelajaran. Dari uraian tersebut maka dapat disimpulkan bahwa pembelajaran remidial merupakan pembelajaran yang ditujukan kepada siswa untuk memperbaiki sebagian atau seluruh kesulitan yang dialami siswa agar dapat mencapai hasil belajar yang maksimal.

Pelaksanaan pembelajaran remidial belum dilaksanakan secara optimal oleh guru. Beberapa penyebabnya adalah jumlah siswa yang besar, setiap siswa memiliki masalah yang 
berbeda, dan diperlukan waktu khusus sementara waktu yang dimiliki guru terbatas. Sebagai dampaknya, siswa tidak tuntas pada satu materi dan mengalami kesulitan mempelajari materi-materi berikutnya. Siswa juga kesulitan menghubungkan konsep-konsep yang terkait karena pada dasarnya Ilmu Fisika bersifat hirarki. Oleh karena itu, diperlukan media pembelajaran berbantuan komputer untuk melaksanan kegiatan remidial bagi siswa

Menurut Rusman (2013), beberapa bentuk penggunaan komputer sebagai media pembelajaran adalah sebagai berikut :

Penggunaan multimedia presentasi : digunakan untuk menjelaskan materi yang sifatnya teoritis, digunakan dalam pembelajaran klasikal dengan grup belajar yang cukup banyak di atas 50 orang.

Multimedia berbasis komputer yang bersifat interaktif, di dalamnya terdapat unsurunsur media secara lengkap yang meliputi sound, animasi, video, teks, dan grafis.

Dari model penerapan multimedia berbasis komputer di atas, multimedia powerpoint menjadi salah satu alternatif media pembelajaran interaktif yang dapat digunakan sebagai pembelajaran remidial. Keunggulan dari multimedia powerpoint adalah dapat digunakan secara mandiri, tidak menggunakan waktu pembelajaran di dalam kelas, serta dapat dilaksanakan secara berulang-ulang. Penelitian mengenai multimedia powerpoint pernah dilakukan oleh Ika Puspitasari (2013). Hasil validasi media pembelajaran berdasarkan tingkat validitas media mencapai rata-rata $84,11 \%$ sedangkan menurut ahli materi sebesar 89,58\%. Jadi dapat disimpulkan bahwa media pembalajaran Multimedia Powerpoint yang dikembangkan sudah memenuhi kriteria layak dan selanjutnya dapat diujicobakan lebih luas.

Pengembangan multimedia powerpoint sebagai media pembelajaran pada materi Suhu dan Kalor didasarkan pada banyaknya fenomena dalam kehidupan sehari-hari yang dapat digali dengan materi ini. Media pembelajaran ini memberikan penjelasan terhadap fenomena yang sering ditemui oleh siswa. Hal tersebut akan menjadi lebih menarik sehingga dapat menumbuhkan minat belajar siswa.

Berdasarkan pemikiran di atas, maka peneliti melakukan penelitian dengan judul "Pengembangan Multimedia Powerpoint Berbasis Problem Solving pada Materi Suhu dan Kalor untuk Siswa Kelas X MIA SMA".

\section{MULTIMEDIA POWERPOINT BERBASIS PROBLEM SOLVING}

Secara etimologis multimedia berasal dari kata multi (Bahasa Latin, nouns) yang berarti banyak, bermacam-macam, dan medium (Bahasa Latin) yang berarti sesuatu yang dipakai untuk menyampaikan atau membawa sesuatu. Kata medium dalam American Heritage Electronic Dictionary (1991) juga diartikan sebagai alat untuk mendistribusikan dan mempresentasikan informasi. Menurut Kamus Besar Bahasa Indonesia, multimedia adalah (1) berbagai jenis sarana, (2) penyediaan informasi pada komputer yang menggunakan suara, grafika, animasi, dan teks. Sedangkan menurut Hofstetter (2001: 2) multimedia adalah penggunaan komputer untuk menyajikan dan menggabungkan teks, suara, gambar, animasi dan video sehingga membuat pengguna dapat bernavigasi, berinteraksi, berkarya dan berkomunikasi. Selain itu terdapat empat komponen yang penting lainnya yaitu : adanya komputer untuk mengatur apa yang akan dilihat dan didengar, dan apa yang akan 
berinteraksi dengan penggunanya; adanya alat bantu (tool) navigasi untuk mengumpulkan, memproses dan menyampaikan informasi dan ide-idenya; adanya koneksi (link) yang menghubungkan informasi yang tersedia.

Media pembelajaran menurut Kemp \& Dayton (1985:28) dalam Arsyad, (2014:23) dapat memenuhi tiga fungsi utama apabila media itu digunakan untuk perorangan, kelompok atau kelompok pendengar yang besar jumlahnya. Tiga fungsi tersebut adalah (1) Memotivasi minat atau tindakan, (2) Menyajikan informasi dan (3) Memberi instruksi. Untuk memenuhi fungsi motivasi, media pembelajaran dapat direalisasikan dengan teknik drama atau hiburan. Hasil yang diharapkan adalah melahirkan minat dan merangsang para siswa. Untuk tujuan informasi, media pembelajaran dapat digunakan dalam rangka penyajian informasi di hadapan sekelompok siswa. Media berfungsi untuk tujuan instruksi dimana informasi yang terdapat dalam media itu harus melibatkan siswa baik dalam benak atau mental maupun dalam bentuk aktivitas yang nyata sehingga pembelajaran dapat terjadi. Berdasarkan prinsipprinsip pengembangan media menurut Arsyad (2014:80-94) media pembelajaran dibedakan menjadi 5, yaitu (1) Media berbasis manusia; (2) Media berbasis cetakan; (3) Media berbasis visual; (4) Media berbasis audio-visual; (5) Media berbasis komputer.

Multimedia powerpoint adalah media pembelajaran yang merupakan gabungan dari slide Powerpoint yang berisi materi dalam bentuk teks, gambar, animasi dan rekaman suara (narasi) sebagai penjelas yang dikemas dalam satu file powerpoint. Tujuan presentasi dengan menggunakan powerpoint yaitu (1) menginformasikan, (2) meyakinkan, (3) membujuk, (4) menginspirasi, dan (5) menghibur

Problem solving adalah upaya individu utau kelompok untuk menentukan jawaban berdasarkan pemahaman yang telah dimiliki sebelumnya dalam rangka memenuhi tuntutan situasi yang tak wajar. Kemampuan memecahkan masalah (problem solving) menuntut siswa untuk mengidentifikasi, mendefinisikan dan memecahkan masalah menggunakan logika serta pemikiran kreatif. Dalam proses ini, peserta didik memiliki pemahaman yang mendalam tentang topik, membangun pengetahuan baru dan mampu membuat keputusan (Crebet, 2011:5).

Berdasar pada Costa (1985) siswa dikatakan mampu memecahkan masalah jika telah mengikuti lima indikator pada proses problem solving yaitu: (1) menggunakan proses berpikir dasar untuk memecahkan kembali masalah yang sudah diketahui atau yang sudah didefinisikan, (2) mengumpulkan fakta tentang masalah dan informasi yang diperlukan, (3) membuat inferensi atau memberikan penyelesaian alternatif dan menguji penyelesaian tersebut, (4) mereduksi penjelasan menjadi lebih sederhana dan mengeliminasi hal-hal yang tidak sesuai dan (5) memberikan solusi ulang untuk membuat generalisasi.

Multimedia Powerpoint berbasis Problem Solving merupakan media pembelajaran yang didalamnya berisi soal-soal. Soal-soal yang ada juga dilengkapi dengan pembahasannya. Pembahasannya dilakukan secara bertahap, sehingga diharapkan siswa dapat mengidentifikasi, mendefinisikan dan memecahkan masalah fisika menggunakan logika serta pemikiran kreatif.

\section{Metode}

Penelitian ini merupakan penelitian pengembangan (Research \& Development) bertujuan menghasilkan video pembelajaran fisika berbasis problem solving pada materi 
Suhu dan Kalor untuk siswa kelas X MIA SMA. Multimedia Powerpoint ini diharapkan dapat meningkatkan kemampuan pemecahan masalah peserta didik. Menurut Sugiyono (2013: 409), penelitian pengembangan memiliki sepuluh langkah. Dalam penelitian ini, langkahlangkah tersebut dimodifikasi menjadi tujuh langkah, yaitu: (1) potensi dan masalah, (2) pengumpulan data, (3) desain produk, (4) validasi desain, (5) revisi desain, (6) uji coba produk, dan (7) revisi produk.

Sugiyono (2013) menyatakan bahwa dalam bidang pendidikan, desain produk baru dapat diuji cobakan setelah divalidasi dan direvisi. Maka video pembelajaran fisika ini terlebih dahulu harus divalidasi oleh ahli. Sebagai validator dalam pengembangan adalah dua orang guru Fisika SMA. Tujuan validasi untuk mengetahui tingkat kelayakan produk yang dikembangkan. Setelah dilakukan validasi, produk kemudian direvisi sesuai yang disarankan. Uji coba terbatas dilakukan pada peserta didik kelas X MIA SMA Negeri 5 Malang. Peserta didik yang menjadi sasaran uji coba terbatas pengembangan video pembelajaran fisika adalah peserta didik kelas X MIA. Pada pelaksanaan uji terbatas ini diwakili oleh sepuluh peserta didik yang ditentukan secara acak (random sampling).

Analisis data yang digunakan dalam penelitian ini yaitu analisis deskriptif kualitatif dan analisis deskriptif kuantitatif. Analisis kualitatif digunakan untuk menganalisis data berupa penilaian dan saran secara tertulis dalam angket validasi produk, angket validasi soal dan pembahasan dan angket keterbacaan video pembelajaran. Analisis kuantitatif digunakan untuk menganalisis data berupa sekor atau angka-angka yang ada dalam angket validasi produk, validasi soal dan pembahasan dan angket keterbacaan multimedia powerpoint. Datadata tersebut diperoleh dari validasi. Data kevalidan yang diperoleh menggambarkan kevalidan multimedia powerpoint berbasis problem solving.

Data tersebut akan dianalisis dengan menghitung nilai rata-rata yang memiliki rumus:

$$
\bar{X}=\frac{\sum x}{n}
$$

$$
\begin{array}{ll}
\text { Keterangan }: \quad & \bar{X} \text { adalah nilai rata-rata } \\
& \sum x \text { adalah jumlah sekor jawaban penilaian } \\
& n \text { adalah jumlah validator }
\end{array}
$$

Selanjutnya diberikan penafsiran dan pengambilan keputusan tentang kualitas video pembelajaran fisika berbasis problem solving menggunakan kriteria validitas yang ditunjukkan pada Tabel 1.

Tabel 1. Kriteria Validitas Analisis Nilai Rata-Rata

\begin{tabular}{ll}
\hline Rata-Rata & Kriteria Kevalidan \\
\hline $3,28-4,00$ & Valid \\
$2,52-3,27$ & Cukup Valid \\
$1,76-2,51$ & Kurang Valid \\
$1,00-1,75$ & Tidak Valid \\
\hline
\end{tabular}

(Diadaptasi dari Arikunto, 2006: 242) 


\section{Hasil dan Pembahasan}

\subsection{Penyajian Data}

Hasil pengembangan produk akhir penelitian dan pengembangan adalah multimedia powerpoint yang terdiri dari 39 slide powerpoint dalam satu file dengan dengan format file .pps. Multimedia powerpoint ini berisi soal-soal materi Suhu dan Kalor beserta pembahasannya. Materi yang dikembangkan mengacu pada Kompetensi Dasar 3.8 yaitu menganalisis pengaruh kalor dan perpindahan kalor pada kehidupan sehari-hari.

Bagian awal multimedia ini selalu diberikan pertanyaan awal yang berhubungan dengan fenomena dikehidupan sehari-hari dari subbab yang akan dipelajari. Pertanyaan pembuka ini berfungsi untuk memancing rasa ingin tahu dan menarik perhatian siswa. Jawaban dari pertanyaan pembuka akan diberikan setelah siswa mempelajari pembahasan soal yang ada di multimedia powerpoint ini. Bagian slide selanjutnya yaitu bagaimana kita belajar?. Bagian ini berisikan gambaran umum langkah-langkah siswa belajar dengan menggunakan multimedia powerpoint berbasis problem solving ini. Bagian selanjutnya yaitu apa yang akan kita pelajari? Bagian ini berisikan tujuan pembelajaran. Bagian terpenting dari multimedia powerpoint yaitu pembahasan soal. Setelah pembahasan soal disajikan jawaban dari pertanyaan awal sebelum memasuki uji kemampuan diri. Uji kemampuan diri berfungsi sebagai evaluasi untuk mengetahui sejauh mana peserta didik sudah memahami apa yang sudah dipelajari dari video pembelajaran fisika berbasis problem solving ini. Berikut adalah contoh gambar tampilan salah satu slide.

Gambar 1. Pertanyaan Awal

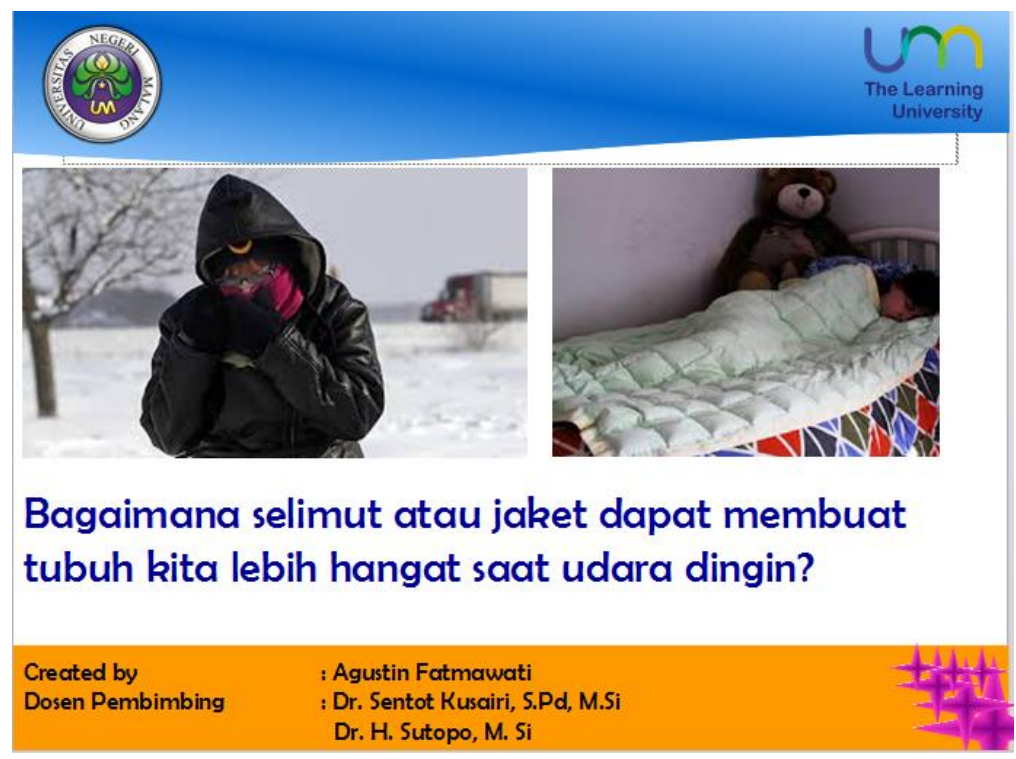


Gambar 2. Pembukaan Video Pembelajaran

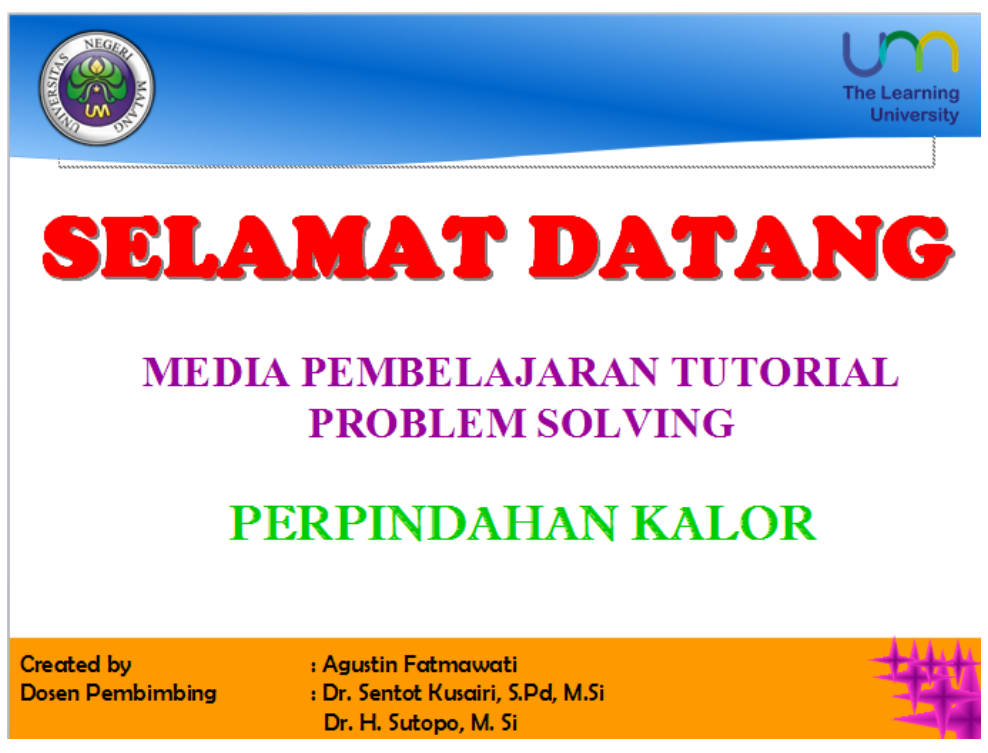

Gambar 3. Bagaimana Kita Belajar?

Bagaimana Kita Belajar?

$\checkmark$ Permasalahan awal

$\checkmark$ Pembahasan

$\checkmark$ Contoh soal dan jawaban

$\checkmark$ Uji Kemampuan Diri 
Gambar 4. Apa yang Akan Kita Pelajari?

Menjelaskan proses perpindahan kalor secara konduksi

Menentukan besar laju kalor konduksi

$\begin{array}{ll}\text { Created by } & \text { : Agustin Fatmawati } \\ \text { Dosen Pembimbing } & : \text { Dr. Sentot Kusairi, S.Pd, M.Si } \\ & \text { Dr. H. Sutopo, M. Si }\end{array}$

Gambar 5. Pembahasan Soal

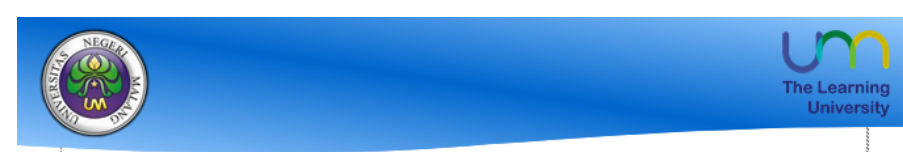

\section{Diketahui :}

Luas kaca jendela (A) : $2,0 \mathrm{~m} \times 1,0 \mathrm{~m}=2,0 \mathrm{~m}^{2}$

Tebal kaca (d) : $3,2 \mathrm{~mm}=3,2 \times 10^{-3} \mathrm{~m}$

Suhu di dalam kaca $\left(\mathrm{T}_{1}\right): 25^{\circ} \mathrm{C}$

Suhu di luar kaca $\left(\mathrm{T}_{2}\right): 30^{\circ} \mathrm{C}$

Konduktivi tas termal kaca $(\mathrm{k}): 0,8 \mathrm{~W} / \mathrm{mK}$

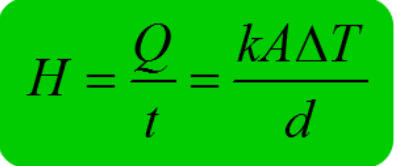

Ditanya :

Laju kalor konduksi $(\mathrm{H})$

\section{Jawaban :}

$$
\begin{aligned}
H & =\frac{k A \Delta T}{d} \\
& =\frac{0,8 \times 2,0 \times(30-25)}{3,2 \times 10^{-3}} \\
& =3750 \mathrm{~J} / \mathrm{s}
\end{aligned}
$$

Gambar 6. Jawaban Pertanyaan Awal

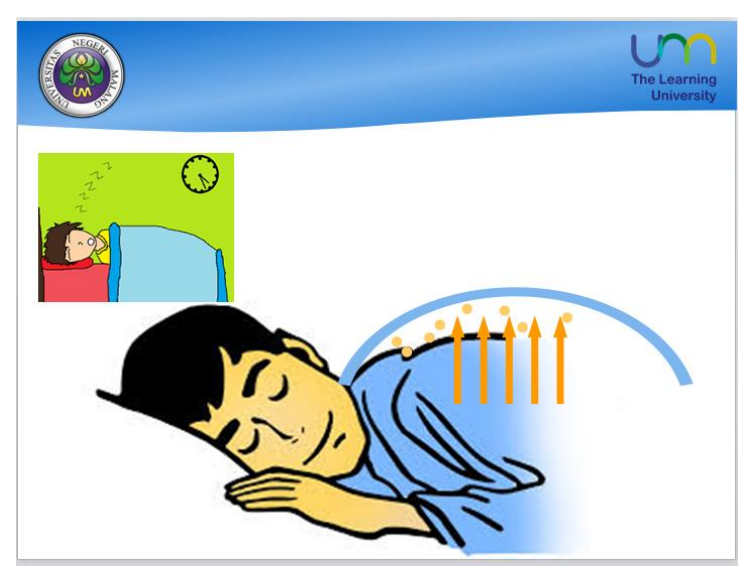




\section{Gambar 7. Uji Kemampuan Diri}

\section{Uji Kemampuan Diri}

\section{1.}

Angin lembah terjadi saat suhu di lembah lebih kecil

dibandingkan dengan suhu di puncak gunung. Jika pada

suatu saat perbedaan suhunya $\Delta \mathrm{T}$ maka angin lembah

tersebut memindahkan energi per detik sebesar $P$. Jika

pada saat perbedaan suhunya $3 \Delta \mathrm{T}$ maka perbandingan

energi angin per detik sebelum dan sesudah adalah...
A. $1: 3$
c. $3: 1$
B. $1: 9$
D. $9: 1$

Validasi produk dilakukan terhadap multimedia powerpoitn secara keseluruhan. Validasi soal dan pembahasan dilakukan secara uji coba terbatas dilakukan terhadap multiemdia powerpoint berbasis problem solving. Data yang diperoleh berupa data kuantitatif dan kualitatif. Data kuantitatif validasi multimedia powerpoint oleh validator dapat dilihat pada Gambar 8.

\section{Gambar 8. Rekapitulasi Data Kuantitatif Hasil Validasi Produk Multimedia Powerpoint Berbasis Problem Solving oleh Validator}

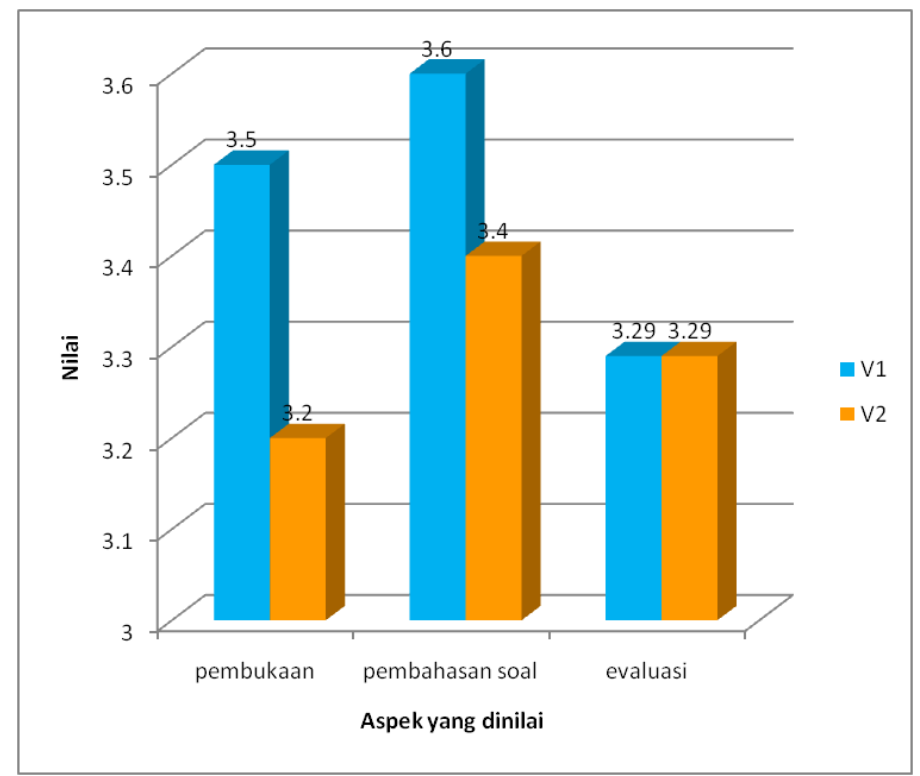

Data kualitatif hasil validasi multimedia powerpoint oleh validator dapat dilihat pada Tabel 1. 
Tabel 4.1. Rekapitulasi Data Kualitatif Hasil Validasi Produk Multimedia Powerpoint Berbasis Problem Solving oleh Validator

\begin{tabular}{cl}
\hline Validator & Saran \\
\hline V1 & Warna bisa dipertajam lagi \\
\hline V2 & Penjelasan terlalu cepat \\
\hline V2 & $\begin{array}{l}\text { Dalam penurunan rumus/pemakaian rumus, hendaknya } \\
\text { tampilannya satu langkah demi satu langkah }\end{array}$ \\
\hline
\end{tabular}

Data kuantitatif validasi soal dan pembahasan ranah materi dan konstruk oleh validator dapat dilihat pada Gambar 9.

\section{Gambar 9. Rekapitulasi Data Kuantitatif Hasil Validasi Soal dan Pembahasan Ranah Materi dan Konstruk oleh Validator}

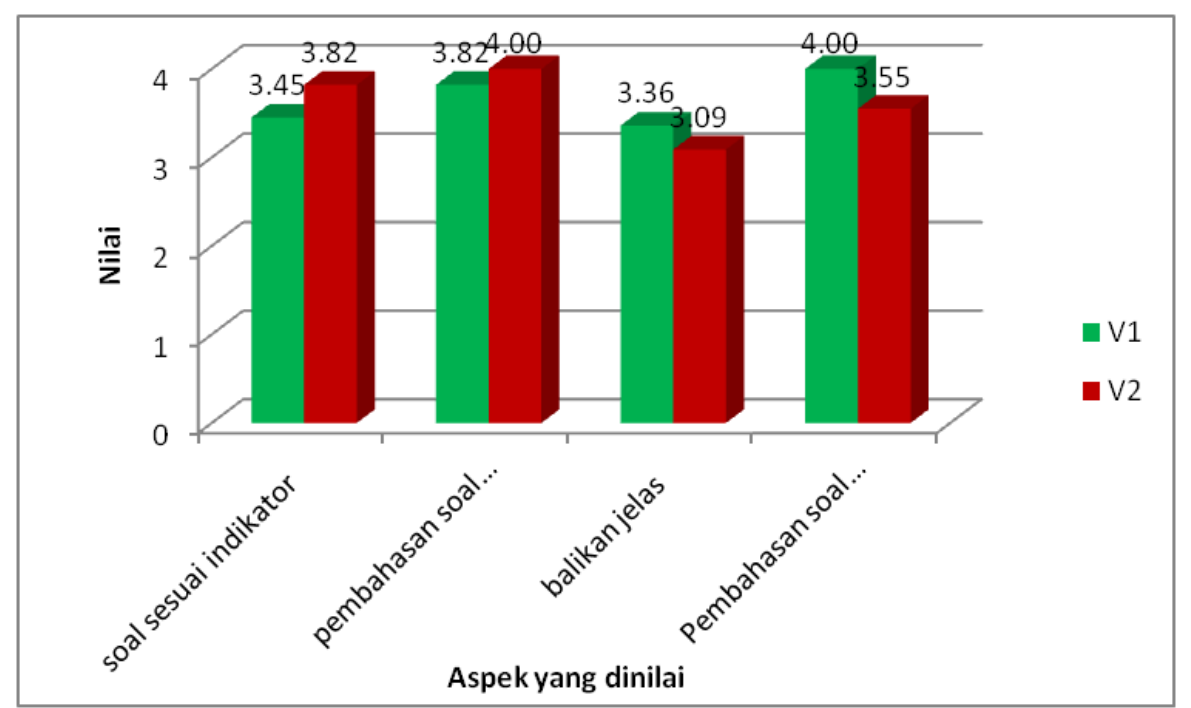

Tabel 2. Rekapitulasi Data Kualitatif Hasil Uji Coba Terbatas Multimedia Powerpoint berbasis Problem Solving

\begin{tabular}{ll}
\hline Responden & Saran \\
\hline Pembahasan soal mudah & Pembahasan mudah dipahami \\
dipahami & Mudah dipahami tetapi penjelasan lewat suara kurang \\
& jelas \\
& Agak terlalu cepat ketika menerangkan \\
& Ya mudah dipahami \\
& Iya, karena cara soal dan pembahasan mudah \\
& Terdapat gambar yang mendukung berlangsungnya \\
& materi tersebut \\
& Karena cara penerangan dengan animasi yang menarik \\
& dan sangat mudah dipahami \\
& Pembahasan soal mudah dipahami dan jelas \\
& Pembahasan sudah lumayan \\
& Suaranya terlalu cepat, sehingga terkadang tidak jelas. \\
& Untuk selanjutnya suaranya lebih dipelankan \\
\hline Teks/ tulisan dapat dibaca & Tulisan mudah dimengerti \\
dengan jelas & Tulisan/kata-katanya sangat jelas dan mudah dibaca \\
\hline
\end{tabular}




\begin{tabular}{|c|c|}
\hline & $\begin{array}{l}\text { Iya, karena teks/tulisan ditayangkan di slide } \\
\text { Teks tulisan dapat dibaca dengan jelas }\end{array}$ \\
\hline $\begin{array}{l}\text { Lebih mudah memahami dan } \\
\text { mengingat materi } \\
\text { perpindahan kalor }\end{array}$ & $\begin{array}{l}\text { Materi yang disampaikan dilengkapi gambar animasi } \\
\text { karena itu mudah dipahami } \\
\text { Memahami materi tetapi lebih fokus pada animasinya } \\
\text { Menjadi ingat tentang materi perpindahan kalor lagi } \\
\text { setelah diajarkan di kelas X } \\
\text { Ya, tidak terlalu sulit mengingatnya jika cara } \\
\text { mengajarnya seperti ini } \\
\text { Penjelasan yang mudah dipahami dnegan ingatan otak } \\
\text { kanan dengan banyaknya animasi yang seru } \\
\text { Menjadi lebih mudah memahami dan mengingat } \\
\text { perpindahan kalor }\end{array}$ \\
\hline $\begin{array}{l}\text { Membuat lebih bersemangat } \\
\text { dalam mempelajari fluida } \\
\text { statis }\end{array}$ & $\begin{array}{l}\text { iya dan ditambah animasi dan contohnya } \\
\text { Menjadikan pelajaran lebih menarik dengan } \\
\text { menggunakan proyektor } \\
\text { Iya sangat semangat dan lebih cepat paham } \\
\text { Karena cara belajarnya menggunakan slide dan itu pun } \\
\text { membosankan } \\
\text { Penerangan yang jelas } \\
\text { Membuat lebih bersemangat memahaminya }\end{array}$ \\
\hline $\begin{array}{l}\text { Kemenarikan produk secara } \\
\text { keseluruhan }\end{array}$ & $\begin{array}{l}\text { Menarik dengan powerpoint bergerak } \\
\text { Lumayan menarik } \\
\text { Penyusunan powerpoint yang berurut } \\
\text { Sangat baik dan sangat mudah dimengerti } \\
\text { Produk sudah menarik }\end{array}$ \\
\hline $\begin{array}{l}\text { Produk tidak membosankan } \\
\text { ketika digunakan }\end{array}$ & $\begin{array}{l}\text { Tidak membosanakan, sangat menarik } \\
\text { Tidak, karena ada powerpoint yang bisa membuat } \\
\text { tambah paham dan bisa mengerjakan soalnya } \\
\text { Tidak membosankan karena banyak gambar yang dapat } \\
\text { mendukung berlangsungnya materi tersebut } \\
\text { Tidak membosankan }\end{array}$ \\
\hline
\end{tabular}

Data hasil uji coba terbatas diperoleh dari angket uji coba terbatas yang diberikan kepada peserta didik kelas XI SMA Negeri 4 Blitar. Data yang diperoleh dari hasil uji coba terbatas adalah data kuantitatif dan kualitatif. Data kuantitatif kemudian dikualitatifkan untuk mengetahui keterbacaan produk oleh siswa. Rekapitulasi data kuantitatif hasil uji coba terbatas multimedia powerpoint berbasis problem solving dapat dilihat pada Tabel 4.3.

\subsection{Analisis Data}

Analisis data hasil validasi multimedia powerpoint berbasis problem solving diperoleh dari rata-rata hasil validasi produk oleh validator, yaitu dua guru fisika kelas X SMA. Aspek produk yang dinilai ada 3, yaitu pembukaan, pembahasan soal dan evaluasi. Hasil rata-rata setiap aspek dari validasi produk oleh validator dapat dilihat pada Tabel 3. 
Tabel 3. Hasil Rata-Rata Setiap Aspek dari Validasi Produk oleh Validator

\begin{tabular}{lllll}
\hline Aspek Penilaian & \multicolumn{2}{l}{ Validator } & $\begin{array}{l}\text { Rata- } \\
\text { rata }\end{array}$ & Kriteria \\
\cline { 2 - 5 } & V1 & V2 & \\
\hline Pembukaan & 3,50 & 3,17 & 3,33 & Valid \\
\hline Pembahasan Soal & 3,60 & 3,40 & 3,50 & Valid \\
\hline Evaluasi & 3,29 & 3,29 & 3,29 & Valid \\
\hline
\end{tabular}

Berdasarkan Tabel 3. diketahui bahwa 3 aspek dari produk video pembelajaran mendapatkan kriteria valid dari hasil validasi ahli.

Berdasarkan hasil analisis data nilai rata-rata soal dan pembahasan secara kesuluruhan adalah 3,64. Dengan rincian 3,77 pada ranah materi dan 3,50 pada ranah konstruksi. Nilai rata-rata tersebut masuk kedalam kriteria valid. Secara keseluruhan dari nilai rata-rata kedua validator dari ranah materi soal No 1. mendapatkan nilai 3,25. Nilai ini termasuk ke dalam kriteria cukup valid. Pada penulisan indikator soal No. 1 terdapat kesalahan penggunaan kata kerja operasional. Semula peneliti menggunakan kata kerja operasional 'menyebutkan' untuk mengarahkan siswa menjawab pertanyaan mengenai penyebab terjadinya konduksi pada logam. Akan tetapi, kata kerja operasional yang benar adalah 'menjelaskan'. Hal tersebut dikarenakan kata 'menyebutkan' merujuk pada jawaban lebih dari satu. Dari ranah materi soal No. 1 mendapatkan nilai rata-rata dari kedua validator sebesar 3,25. Nilai tersebut masuk ke dalam kriteria cukup valid. Artinya pada soal No. 1 memerlukan perbaikan dari segi materinya, yaitu memperbaiki soal sesuai dengan indikator dan pembahasan soal dengan benar.Hasil rata-rata setiap aspek dari uji coba terbatas multimedia powerpoint berbasis problem solving oleh peserta diidk dapat dilihat pada Tabel 4.

Tabel 4. Hasil Rata-Rata Setiap Aspek dari Uji Coba Terbatas Video Pembelajaran oleh Peserta Didik

\begin{tabular}{lll}
\hline Aspek yang dinilai & Rata-rata & Kriteria \\
\hline Pembahasan soal mudah dipahami & 3,52 & Sesuai \\
\hline Teks/ tulisan dapat dibaca dengan jelas & 3,69 & Sesuai \\
\hline $\begin{array}{l}\text { Lebih mudah memahami dan mengingat } \\
\text { materi tentang Perpindahan Kalor }\end{array}$ & 3,34 & Sesuai \\
\hline $\begin{array}{l}\text { Membuat lebih bersemangat dalam } \\
\text { mempelajari Perpindahan Kalor }\end{array}$ & 3,34 & Sesuai \\
\hline Kemenarikan produk secara keseluruhan & 3,34 & Sesuai \\
\hline $\begin{array}{l}\text { Produk tidak membosankan ketika } \\
\text { digunakan }\end{array}$ & 3,31 & Sesuai \\
\hline
\end{tabular}

Berdasarkan Tabel 4. diketahui bahwa semua aspek dari multimedia powerpoint berbasis problem solving mendapatkan kriteria sesuai dari hasil uji coba terbatas. Hal ini menunjukkan bahwa multimedia powerpoint berbasis problem solving yang dikembangkan dalam penelitian pengembangan ini memiliki tingkat keterbacaan yang baik dari siswa. Siswa 
tidak mengalami kesulitan yang berarti dalam memahami multimedia powerpoint berbasis problem solving yang dikembangkan.

Berdasarkan data hasil uji coba multimedia powerpoint berbasis problem, diketahui bahwa multimedia powerpoint yang telah disusun memiliki nilai rata-rata 3,41. Berdasarkan kriteria skala Likert, multimedia powerpoint berbasis problem solving yang telah disusun secara keseluruhan memiliki kriteria valid dan memiliki tingkat keterbacaan yang baik dari peserta didik.

\section{Simpulan}

\subsection{Kesimpulan}

Multimedia powerpoint yang dikembangkan terdiri dari 3 bagian yaitu pembukaan, pembahasan dan evaluasi. Materi yang dibahas dalam pengembangan multimedia powerpoint berbasis problemsolving ini adalah materi suhu dan kalor. Materi suhu dan kalor ini sesuai dengan Kompertensi Dasar 3.8 yaitu menganalisis pengaruh kalor dan perpindahan kalor pada kehidupan sehari-hari. Multimedia ini khusus membahas satu sub bab yaitu perpindahan kalor yang terdiri atas konduksi, konveksi dan radiasi.

Pengembangan multimedia ini dibentuk dalam kemasan satu file powerpoint yang telah mencakup materi yang dibahas. Pengemasan produk berupa multimedia membuat siswa dapat dengan mudah membukanya melalui komputer atau laptop bahkan smartphone dengan aplikasi Office. Kemudahan ini selanjutnya yang juga menjadi salah satu kelebihan produk yang dikembangkan ini.

Setelah direvisi suara yang ada di multimedia powerpoint ini menjadi lebih jelas. Khususnya pada slide pembahasan soal. Selain itu pada pembahasan soal juga sudah dicantumkan pilihan jawaban yang benar. Sebelumnya peneliti hanya memberikan pembahasan jawaban yang benar. Pembahasan yang diberikan berupa teks juga telah diberikan secara bertahap. Pada awalnya peneliti hanya memberikan narasi jawaban pembahasan soal secara bertahap namun teks pembahasan ditayangkan secara keseluruhan.

Berdasarkan Permendikbud No. 64 tahun 2013 tentang Standar Isi, salah satu hal yang harus ada dalam bahan ajar adalah dapat membantu peserta didik menganalisis pengetahuan terkait dengan penyebab fenomena dan kejadian. Pada multimdia powerpoint ini disajikan fenomena dan kejadian dari kehidupan sehari-hari yang berhubungan dengan konsep yang akan dipelajari. Disajikannya permasalahan kehidupan nyata dan pengkajiaan dari sudut pandang fisika, diharapkan dapat membantu siswa menganalisis kejadian tersebut ditinjau dari sudut pandang fisika.

Kekuatan produk yang dikembangkan terletak pada latihan pemecahan masalahnya. Produk yang dikembangkan fokus untuk mengembangkan kemampuan pemecahan masalah (problem solving) siswa. Sehingga dalam multimdia powerpoint ini berisi soal-soal beserta penyelesaiannya. Penyelesaiannya dilakukan secara bertahap, sehingga dapat mempermudah siswa dalam mempelajarinya. Hal ini merupakan salah 
satu kelebihan dari tahapan problem solving. Menurut Eko (2012) problem solving memiliki kelebihan dapat meningkatkan kemampuan memahami masalah secara umum, memahami masalah secara fisika, kemampuan matematika dan kemampuan menjalankan rencana pemecahan.

Berdasarkan hasil uji coba produk, siswa menyatakan bahwa produk multimdia powerpoint pembelajaran ini sangat menarik. Karena tampilannya dilengkapi dengan teks, gambar dan suara yang dinarasikan. Dengan menggunakan multimdia powerpoint ini siswa dapat lebih bersemangat dan lebih mudah memahami materi perpindahan kalor.

Kelemahan produk berkaitan dengan pemecahan masalah adalah variasi dan jumlah soal latihan yang dirasa kurang oleh peneliti. Karena sebisa mungkin soal latihan dan penyelesaian dibuat lebih banyak agar siswa dapat memperoleh sumber belajar yang lebih banyak. Produk multimdia powerpoint ini tidak interaktif, hal ini dikarenakan tidak ada sistem navigasi pada produk. Produk tidak terdapat sistem navigasi dikarenakan produk yang dikembangkan fokus pada media audiou-visual berbentuk powerpoint berbasis problem solving. Kesesuaian produk dengan pendekatan ilmiah juga kurang, hal ini dikarenakan pada media ini tidak memfasilitasi siswa pada tahap mencoba. Pengembangan yang dilakukan hanya sampai pada tahap revisi produk. Dengan menyisakan uji coba pemakaian, revisi produk dan produksi masal. Perlu dilakukan uji lebih lanjut karena ujicoba hanya ditekankan pada pengamatan secara konstruk saja.

\subsection{Saran}

Berdasarkan hasil uji kelayakan dan uji coba terbatas kepada siswa, produk yang dihasilkan dinilai cukup layak. Sehingga multimdia powerpoint berbasis problem solving pada materi Suhu dan Kalor ini dapat di uji cobakan dalam skala luas agar bisa diproduksi secara masal. Saran yang diberikan untuk pemanfaatan produk adalah digunakan sebagai salah satu media pembelajaran yang bisa digunakan secara mandiri oleh siswa. Multimedia powerpoint berbasis problemsolving ini dapat diberikan guru setelah siswa mengikuti kegiatan belajar di kelas. Hal ini dikarenakan Multimedia powerpoint ini berfungsi sebagai suplemen dan komplemen bagi pembelajaran di dalam kelas. Setelah kegiatan belajar selesai guru dapat mengcopykan file powerpoint ini ke siswa untuk dipejalari secara mandiri.

Saran yang diberikan untuk diseminasi produk adalah dengan menyebarkan produk ke guru fisika dan siswa yang berkenan atau membutuhkan multimdia powerpoint berbasis problem solving. Diseminasi dapat dilakukan secara langsung maupun secara online. Diseminasi secara langsung misalnya dengan menggunakan keping DVD ataupun dengan menggunakan alat untuk menyimpad data lainnya. File yang sudah dicopykan siap dibuka melalui aplikasi Micrososft Excel yang ada di PC komputer, laptop maupun smartphone. Selain itu dapat juga dengan mentransfer file ini dengan menggunakan bluetooth. Secara online diseminasi bisa memanfaatkan media internet dengan memasukkannya ke dalam youtube, blog, forum, atau web.

Saran untuk pengembangan lebih lanjut bisa dilakukan dengan melakukan penyempurnaan dari kekurangan-kekurangan produk yang ada. Untuk 
pengembangan produk lebih lanjut yang pertama dapat dilakukan dengan menambahkan jumlah variasi soal dan pembahasan soal. Kemudian agar lebih sesuai dengan konsep pendekatan ilmiah berdasarkan kurikulum yang berlaku hendaknya menambahkan fasilitas mencoba pada produk. Sebagai pilihan tambahan pengembangan produk juga dapat dilakukan dengan menambahkan sistem navigasi. Saran penelitian lebih lanjut dapat dilakukan dengan melanjutkan pengembangan ini pada tahap uji empiris agar diketahui efektifitas produk yang diharapkan karena pengembangan hanya berhenti pada tahap uji coba kelompok yang lebih kecil.

\section{Daftar Rujukan}

Crebert, G., Patrick, C. J., Cragnolini, V., Smith, C., Worsfold, K., \& Webb, F. (2011). Griffith graduate attributes teamwork skills toolkit. Griffith Graduate Attributes Teamwork Skills Toolkit.

Costa, A. L. (1985). Developing minds: A resource book for teaching thinking Alexandria. VA: ASCD.

Gok, T. (2010). The general assessment of problem solving processes and metacognition in physics education. International Journal of Physics \& Chemistry Education, 2(2), 110-122.

Hofstetter, Fred T. (2001). Multimedia Literacy. Third Edition. New York: McGraw-Hill International Edition

Pusat Bahasa. (2011). Kamus Besar Bahasa Indonesia v1.1. (Online), ～(http://ebsoft.web.id), diunduh pada 2 September 2014

Puspitasari, I. (2013). Pengembangan multimedia powerpoint pokok bahasan fluida sebagai sarana belajar mandiri siswa kelas XI SMA (Doctoral dissertation, Universitas Negeri Malang).

dan Kebudayaan, K. P. (2013). Permendikbud no. 69/2013: Kerangka dasar dan struktur kurikulum SMA/MA. Jakarta: Kemendikbud.

Rusman, B., \& berbasis Komputer, P. (2013). Mengembangkan Profesionalisme Abad 21. Bandung: Alfabeta.

Santrock, J. W. (2008). Educational psychology.(D. Angelica, Trans.) Jakarta: Salemba Humanika.

Severinus, D. (2013, September). Pembelajaran Fisika Seturut Hakekatnya Serta Sumbangannya dalam Pendidikan Karakter Siswa. In lpf2013.

Suharsimi, A. (2006). Prosedur penelitian suatu pendekatan praktik. Jakarta: Rineka Cipta, 120-123.

Sukma, F. B. (2013). Pengembangan bahan ajar berbantuan komputer (CAI) fisika berbasis masalah untuk mengembangkan kemampuan problem solving siswa kelas X/FB Bayon Sukma (Doctoral dissertation, Universitas Negeri Malang).

Sugiyono. (2013). Metode Penelitian Pendidikan. Bandung: Alfabeta

Vaughan, Tay. (2004). Multimedia: Making It Work 6th Edition. Singapore: The McGraw Hill 